\title{
Sub Clinical Pregnancy Toxaemia Diagnostic Indicators and its Therapeutic Evaluation in Goats
}

\author{
Varadarajan Vijayanand $^{1 *}$, Mani Balagangatharathilagar ${ }^{2}$, Tensingh Gnanaraj ${ }^{3}$ and Subbiah Vairamuthu ${ }^{4}$ \\ ${ }^{1}$ Resident Veterinary Services Section, Madras Veterinary College, Tamil Nadu Veterinary and Animal Sciences University, \\ Chennai, Tamil Nadu, INDIA \\ ${ }^{2}$ Department of Veterinary Clinical Medicine, Madras Veterinary College, Tamil Nadu Veterinary and Animal Sciences \\ University, Chennai, Tamil Nadu, INDIA \\ ${ }^{3}$ Livestock Farm Complex, Madhavaram Milk Colony, Tamil Nadu Veterinary and Animal Sciences University, Chennai, \\ Tamil Nadu, INDIA \\ ${ }^{4}$ Centralized Clinical Laboratory, Madras Veterinary College, Tamil Nadu Veterinary and Animal Sciences University, \\ Chennai, Tamil Nadu, INDIA \\ *Corresponding author: VVijayanand; E-mail: drvjanand@gmail.com
}

Received: 06 May, 2021

Revised: 28 May, 2021

Accepted: 30 May, 2021

\begin{abstract}
A total of 516 adult non descriptive does brought to Veterinary University Peripheral Hospital, Madhavaram Milk Colony, Chennai - 51, during the period October 2016 to September 2018. were treated for various medical conditions. Of this, 72 does were in their last six weeks of gestation carrying twins/triplets and presented with the history of off feed. They were subjected to determination of blood beta hydroxybutyric acid (BHBA) concentration by means of a portable blood ketone and glucose monitoring system and qualitative urinalysis using urine dip stick. Does with BHBA $>0.8 \mathrm{mmol} / \mathrm{L}$ and $<1.6$ $\mathrm{mmol} / \mathrm{L}$ were classified as sub-clinical pregnancy toxaemic group $(\mathrm{n}=12)$ while the remaining does BHBA level were within normal range $(<0.8 \mathrm{mmol} / \mathrm{L})$. The control animals were selected from adult Tellicherry does in the age group of 2 to 4 years maintained at Livestock Farm Complex (LFC), Madhavaram Milk Colony, Chennai - 600051 and a private goat farm (ECR Goat Farm), Injambakkam, Chennai. The sub- clinical pregnancy toxaemic group were resorted to treatment with intravenous glucose therapy (5 per cent Dextrose) and oral administration of glycerine for 3-4 days @ $25 \mathrm{ml}$ twice daily supported with parenteral Vitamin $\mathrm{B}_{1}, \mathrm{~B}_{6} \& \mathrm{~B}_{12}$ therapy with an overall cure rate of $100 \%$.. Reliable diagnostic indicators for sub-clinical form of pregnancy toxaemia include presence of ketone body in urine and BHBA $>0.8 \mathrm{mmol} / \mathrm{L}$ and $<1.6 \mathrm{mmol} / \mathrm{L}$.
\end{abstract}

\section{HIGHLIGHTS}

(0 Periparturient mortality in goats have a great economic impact on the livelihood of marginal farmers.

(0 Reliable diagnostic indicators of negative energy balance in the primary stage of the disease are the need of the hour for better herd health management.

Keywords: Sub-clinical Pregnancy Toxaemic Goats, Diagnostic Indicators, Therapeutic Evaluation

Pregnancy toxaemia also called as gestational ketosis, twin-lamb disease, ketosis of pregnancy, kid disease, lambing sickness, kidding paralysis and lambing or kidding ketosis Sharma et al., 2014) is a metabolic disease affecting pregnant ewes and does after a period of negative energy balance (NEB) and impaired gluconeogenesis (Lima et al., 2012). Pregnancy toxaemia normally occur in the last trimester (last 6 to 4 weeks) of gestation in goat and sheep as a result of negative energy balance consequent

How to cite this article: Vijayanand, V., Balagangatharathilagar, M., Gnanaraj, T. and Vairamuthu, S. (2021). A study on epidemiology and haematological changes of fascioliasis in cattle and its therapeutic management with indigenous medicinal plants. J. Anim. Res., 11(3): 457 465

Source of Support: None; Conflict of Interest: None 
to enhanced requirement for glucose by the developing foetuses (Schlumbohm and Harmeyer, 2008). Risk factors include multiple fetuses, poor quality of ingested energy, decreased dietary energy level, genetic factors, obesity, lack of good body condition, high parasitic load, stress factors and multiple pregnancies (Hefnawy et al., 2011). The disease is characterized by hypoglycaemia, low concentrations of hepatic glycogen, increased fat catabolism leading to high plasma concentration of nonesterified fatty acids (NEFA), high concentration of ketone bodies (hyperketonaemia) and high mortality rate (Van Saun, 2000). The mortality rate can attain $100 \%$ even with the initiation of treatment due to severe irreversible organ damage. In goat farming reliable diagnostic indicators of negative energy balance in the primary stage of the disease are the need of the hour for better herd health management.

\section{MATERIALS AND METHODS}

The study was carried out at Veterinary University Peripheral Hospital (VUPH), Madhavaram Milk Colony, Chennai - 6000 051, Livestock Farm Complex (LFC), Madhavaram Milk Colony, Chennai - 600051 and a private goat farm (ECR Goat Farm), Injambakkam, Chennai during the period October 2016 to September 2018. The control animals were selected from adult Tellicherry does in the age group of 2 to 4 years maintained at Livestock Farm Complex (LFC), Madhavaram Milk Colony, Chennai - 600051 and a private goat farm (ECR Goat Farm), Injambakkam, Chennai. Pregnant does ( $\mathrm{n}=$ 12) carrying twins / triplets, without exhibiting signs of pregnancy toxaemia throughout gestation at Livestock Farm Complex, Madhavaram Milk Colony and Pregnant does $(n=12)$ carrying twins / triplets, without exhibiting signs of pregnancy toxaemia throughout gestation at ECR Goat Farm, Injambakkam, Chennai served as control. Does in their last six weeks of gestation carrying twins / triplets presented with the history of off feed to Veterinary University Peripheral Hospital, Madhavaram Milk Colony, Chennai (72 does) were subjected to determination of blood BHBA concentration by means of a portable blood ketone and glucose monitoring system and qualitative urinalysis using urine dip stick. The pregnant does were subjected to radiography for conformation of pregnancy and assessment of fetal numbers. Does with BHBA $>0.8$ $\mathrm{mmol} / \mathrm{L}$ and $<1.6 \mathrm{mmol} / \mathrm{L}$ were classified as sub-clinical pregnancy toxaemia.

\section{Parameters included in the Study}

\section{Clinical Signs}

The clinical signs exhibited by the pregnant does were recorded.

\section{Blood BHBA concentration}

The blood BHBA concentration was determined using a portable blood ketone and glucose monitoring system (Fig. 1) (Free Style Optium Neo H-Abbott ${ }^{\circledR}$ ) (Pichler et al., 2014).

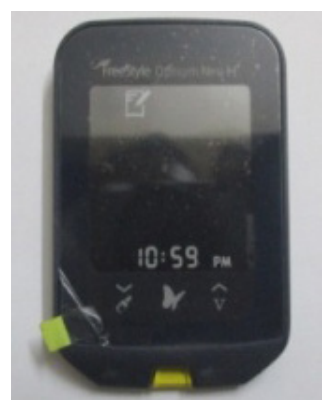

Fig. 1: Portable Blood ketone monitoring system

\section{Urine sample}

Urine samples were obtained after a voluntary micturition or induced by covering the nose and mouth of does for a few seconds (Albay et al., 2014). The urine samples were analyzed using Multistix 10 SG reagent strip (Siemens Healthcare Private Limited, India) for qualitative determination of ketone bodies, glucose and protein (Emam and Galhoom, 2008). The test strips were dipped into the collected urine and immediately compared with the colour chart provided on the label of the urine test strip container to determine the presence of ketone, glucose and protein in the urine. (Fig 2).

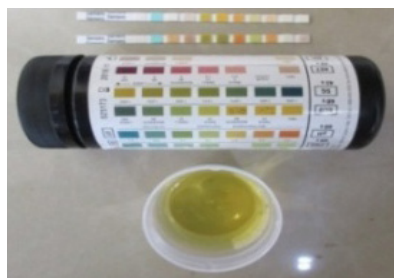

Fig. 2: Urinalysis using Multistix 10SG reagent strip in sub clinical pregnancy toxaemic doe 


\section{Ultrasonography}

The pregnant does were subjected to ultrasonography to assess the stage of gestation and the viability of the fetuses. The estimated gestational age of the fetus in weeks was calculated using the formula $\mathrm{Y}=4.712+0.445 \mathrm{X}$, where $\mathrm{Y}=$ Gestational age $(\mathrm{wks})$ and $\mathrm{X}=$ Fetal parameter $(\mathrm{cm})$ in case of crown rump length and $\mathrm{Y}=2.675+3.229 \mathrm{X}$ where $\mathrm{Y}=$ Gestational age (wks) and $\mathrm{X}=$ Fetal parameter $(\mathrm{cm})$ in case of bi-parietal diameter (Abdelghafar et al., 2011).

\section{Radiography}

To confirm pregnancy and assess the foetal numbers (Fig. $3 \& 4)$.

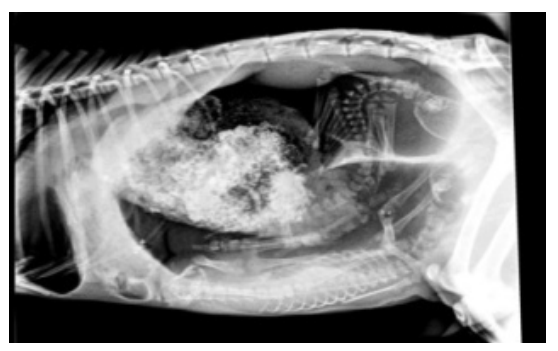

Fig. 3: Radiography in pregnant doe - Twins

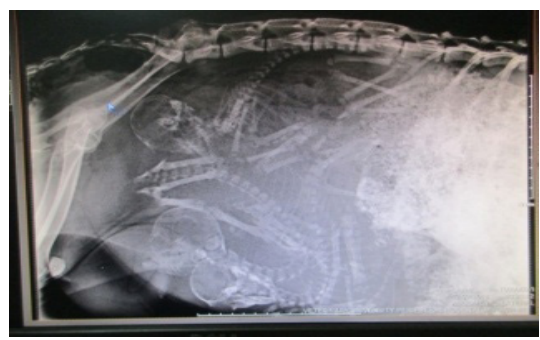

Fig. 4: Radiography in pregnant doe - Triplets

\section{Haematology}

Haematological investigation with automated haematology analyzer (Mindray BC 2800 Vet): haemoglobin (g/dL, packed cell volume $(\%)$, red blood cell $\left(\mathrm{X} 10^{6} / \mathrm{cmm}\right)$, white blood cells $(/ \mathrm{cmm})$ and differential count.

\section{Serum Biochemistry}

Serum biochemical parameters - blood urea nitrogen $(\mathrm{mg} / \mathrm{dL})$, creatinine $(\mathrm{mg} / \mathrm{dL})$, aspartate aminotransferase
(IU/L), alanine aminotransferase (IU/L), glucose $(\mathrm{mg} / \mathrm{dL})$ and total protein $(\mathrm{g} / \mathrm{dL})$ were estimated in an automated biochemical analyzer (A 15 Random Access Analyzer).

\section{Serum Electrolytes}

The serum electrolytes - sodium $(\mathrm{mmol} / \mathrm{L})$, potassium $(\mathrm{mmol} / \mathrm{L})$, calcium $(\mathrm{mg} / \mathrm{dL})$, magnesium $(\mathrm{mg} / \mathrm{dL})$ and chloride $(\mathrm{mmol} / \mathrm{L})$ were estimated in an automated electrolyte analyzer. (Diestro $103 \mathrm{AP}$ )

\section{Serum Metabolites}

The serum was stored at $-20^{\circ} \mathrm{C}$ until analysis of levels of serum metabolites namely beta hydroxybutyric acid (BHBA) $(\mu \mathrm{mol} / \mathrm{L})$ and non-esterified fatty acid (NEFA) $(\mu \mathrm{mol} / \mathrm{L})$ by Enzyme Linked Immunosorbent Assay (ELISA) method using goat specific BHBA and NEFA ELISA kits (My Bio Source Inc., USA) while the level of serum cortisol (nmol/L) was analyzed by Enzyme Linked Immunosorbent Assay (ELISA) method using goat specific Cortisol ELISA kit (Cusabio Biotech Co. Ltd.,) as per the manufacturer's instruction and the optical density value was read in the ELISA microplate reader at $450 \mathrm{~nm}$.

\section{Therapy}

The sub-clinical pregnancy toxaemic does were treated with intravenous glucose therapy ( 5 per cent Dextrose) and oral administration of glycerine for 3-4 days @ 25 $\mathrm{ml}$ twice daily supported with parenteral Vitamin $\mathrm{B}_{1}, \mathrm{~B}_{6}$ $\& \mathrm{~B}_{12}$ therapy. The response to therapy was evaluated 3-5 days post initiation of therapy and the efficacy was assessed based on the clinical signs, haematology, serum biochemistry, metabolic and hormonal parameters.

\section{Cure rate and case fatality rate}

The cure rate and case fatality rate were evaluated based on the response to treatment.

\section{Statistical Analysis}

The data collected were statistically analyzed by One Way Analysis of Variance (ANOVA) using Statistical Software IBM $^{\circledR}$ SPSS $^{\circledR}$ Version 20.0 for Windows ${ }^{\circledR}$ and critically discussed. 


\section{RESULTS AND DISCUSSION}

The clinical signs recorded in sub-clinical pregnancy toxaemia anorexia $(100 \%)$, dullness in $10(83 \%)$, bruxism in $7(58 \%)$. The dung voiding was normal in all the does with a standing posture and normal carriage of head and neck.

The BHBA concentration in blood of non pregnant does and pregnant does without exhibiting signs of pregnancy toxaemia ranged between $0.2 \mathrm{mmol} / 1$ to $0.6 \mathrm{mmol} / 1$ (Fig. 5) and between $0.9 \mathrm{mmol} / 1$ to $1.5 \mathrm{mmol} / 1$ in subclinical pregnancy toxaemic does (Fig. 6) which were in accordance to Andrews (1997). The values obtained in the portable ketone meter were immediate, reliable and highly useful in screening does for pregnancy toxaemia under field conditions. The human ketone meter can be successfully applied to estimate beta hydroxybutyrate level in goats at field conditions due to the non availability of other reliable spot tests (Yadav et al., 2016).

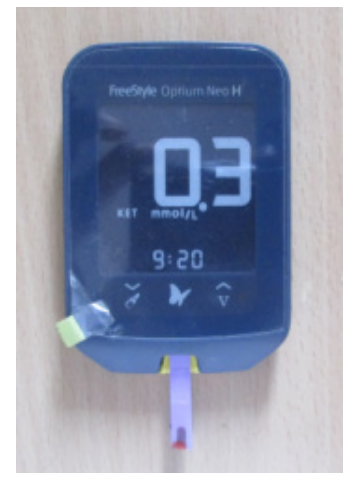

Fig. 5: Blood BHBA in pregnant doe without signs of pregnancy toxaemia

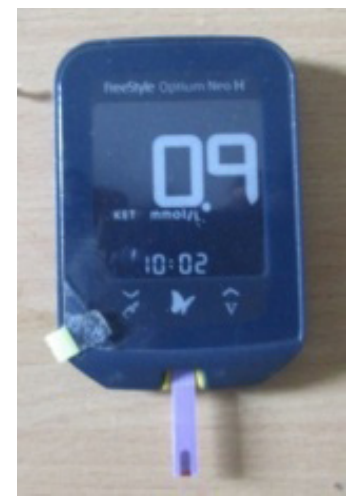

Fig. 6: Blood BHBA in Sub-clinical Pregnancy Toxaemic Doe
Urinalysis in control group indicated absence of ketone bodies, glucose and protein. In the sub-clinical pregnancy toxaemic group, presence of trace quantities of ketone bodies in the urine of 9 does $(75 \%)$ and small quantities in 3 does $(25 \%)$ might be attributed to the increased fat hydrolysis (Cleon, 1988). Protein was completely absent in the urine sample of all the does while trace quantities of glucose was observed in the urine of 6 does $(50 \%)$ while the remaining 6 does $(50 \%)$ had $1+$ grading. The qualitative analysis of urine samples for the presence of ketone bodies, glucose and protein under field conditions can be carried out with accuracy and reliability using Multistix 10 SG reagent strips (Emam and Galhoom, 2008).

The Mean \pm S.E. of Haemoglobin, Packed Cell Volume, Red Blood Cells and White Blood Cells in control (LFC and ECR Goat Farm) and pre and post treatment of subclinical pregnancy toxaemic group are presented in Table 1. The haemoglobin, packed cell volume and red blood cell values in sub-clinical pregnancy toxaemic group were higher than the control. Highly significant $(\mathrm{P} \leq 0.01)$ difference was observed between pre and post treatment compared to that of control. The significant increase of the above values in the pregnancy toxaemic does may be due to hemoconcentration and dehydration (Hefnawy et al., 2011).

The Mean \pm S.E. of Differential Count in control (LFC and ECR Goat Farm) and pre and post treatment of subclinical pregnancy toxaemic group are presented in Table 2. Neutrophilia was observed in sub-clinical pregnancy toxaemic group and showed a decreasing trend during the course of treatment. Highly significant $(\mathrm{P} \leq 0.01)$ difference was observed between pre and post treatment compared with control. The neutrophilia might be due to the increased cortisol level which created a movement of granulocytes from the bone marrow to the peripheral blood (Alidadi et al., 2012). The Lymphocytes in sub-clinical pregnancy toxaemic group was lower than the control and showed an increasing trend during the course of treatment. Highly significant $(\mathrm{P} \leq 0.01)$ difference was observed between pre and post treatment compared to that of control. Lymphopenia in sub-clinical pregnancy toxaemic does might be due to the toxic and sub-toxic concentration of beta hydroxybutyrate and acetoacetate in blood which inhibit the lymphocytic proliferation (Franklin and Young, 1991) or may be due to increased cortisol level (Alidadi 
Table 1: Mean \pm S.E. of Haemoglobin, Packed Cell Volume, Red Blood Cells and White Blood Cells in Control and Pre and Post Treatment of Sub Clinical Pregnancy Toxaemic Group

\begin{tabular}{|c|c|c|c|c|c|c|c|}
\hline \multirow{3}{*}{ Parameters } & \multicolumn{4}{|c|}{ Control : Pregnant Does - Gestation in days } & \multicolumn{2}{|c|}{$\begin{array}{l}\text { Sub Clinical Pregnancy } \\
\text { Toxaemic Group }\end{array}$} & \multirow{3}{*}{ 'F' value } \\
\hline & \multicolumn{2}{|c|}{$\begin{array}{l}\text { Livestock Farm Complex } \\
(\mathrm{n}=12)\end{array}$} & \multicolumn{2}{|c|}{$\begin{array}{l}\text { ECR Goat Farm } \\
(\mathrm{n}=12)\end{array}$} & \multirow{2}{*}{$\begin{array}{l}\text { Pre Treatment } \\
-(n=12)\end{array}$} & \multirow{2}{*}{$\begin{array}{l}\text { Post Treatment } \\
(\mathrm{n}=12)\end{array}$} & \\
\hline & 120 days & 150 days & 120 days & 150 days & & & \\
\hline$\overline{\text { Haemoglobin }(\mathrm{g} / \mathrm{dL})}$ & $8.55^{\mathrm{a}} \pm 0.07$ & $8.53^{\mathrm{a}} \pm 0.05$ & $8.45^{\mathrm{a}} \pm 0.07$ & $8.45^{\mathrm{a}} \pm 0.04$ & $9.0^{\mathrm{b}} \pm 0.15$ & $9.01^{\mathrm{b}} \pm 0.13$ & $6.87 * *$ \\
\hline $\begin{array}{l}\text { Packed Cell Volume } \\
(\%)\end{array}$ & $24.4^{\mathrm{ab}} \pm 0.84$ & $26.32^{\mathrm{bc}} \pm 0.83$ & $22.80^{\mathrm{a}} \pm 0.87$ & $23.23^{\mathrm{a}} \pm 0.83$ & $27.75^{c} \pm 0.10$ & $27.02^{\mathrm{c}} \pm 0.20$ & $10.33 * *$ \\
\hline $\begin{array}{l}\text { Red Blood Cells } \\
\left(\mathrm{X} 10^{6} / \mathrm{cmm}\right)\end{array}$ & $15.34^{\mathrm{a}} \pm 0.73$ & $16.04^{\mathrm{a}} \pm 0.73$ & $15.19^{\mathrm{a}} \pm 0.69$ & $15.99^{\mathrm{a}} \pm 0.61$ & $18.66^{b} \pm 0.08$ & $18.57^{\mathrm{b}} \pm 0.06$ & $9.26 * *$ \\
\hline $\begin{array}{l}\text { White Blood Cells } \\
(/ \mathrm{cmm})\end{array}$ & $\begin{array}{l}19112.5 \pm \\
2046.28\end{array}$ & $\begin{array}{l}20250 \pm \\
1399.74\end{array}$ & $\begin{array}{l}20741.66 \pm \\
1773.3\end{array}$ & $\begin{array}{l}20558.33 \pm \\
1496.93\end{array}$ & $\begin{array}{l}22091.67 \pm \\
166.27\end{array}$ & $\begin{array}{l}21683.33 \pm \\
203.69\end{array}$ & $0.59^{\mathrm{NS}}$ \\
\hline
\end{tabular}

NS - Not Significant; ** Highly Significant $(\mathrm{P} \leq 0.01)$; Means bearing the same superscript within the same row do not differ significantly.

Table 2: Mean \pm S.E. of Differential Count in Control and Pre and Post Treatment of Sub Clinical Pregnancy Toxaemic Group

\begin{tabular}{|c|c|c|c|c|c|c|c|}
\hline \multirow{3}{*}{ Parameters } & \multicolumn{4}{|c|}{ Control : Pregnant Does - Gestation in days } & \multicolumn{2}{|c|}{$\begin{array}{c}\text { Sub Clinical Pregnancy Toxaemic } \\
\text { Group }\end{array}$} & \multirow{3}{*}{ 'F'value } \\
\hline & \multicolumn{2}{|c|}{$\begin{array}{l}\text { Livestock Farm complex } \\
(\mathrm{n}=12)\end{array}$} & \multicolumn{2}{|c|}{$\begin{array}{l}\text { ECR Goat Farm } \\
(\mathrm{n}=12)\end{array}$} & \multirow[t]{2}{*}{$\begin{array}{l}\text { Pre Treatment } \\
(\mathrm{n}=12)\end{array}$} & \multirow[t]{2}{*}{$\begin{array}{l}\text { Post Treatment } \\
(\mathrm{n}=12)\end{array}$} & \\
\hline & 120 days & 150 days & 120 days & 150 days & & & \\
\hline Neutrophils (\%) & $32.12^{\mathrm{a}} \pm 0.63$ & $32.0^{\mathrm{a}} \pm 0.46$ & $32.75^{\mathrm{a}} \pm 0.46$ & $33.16^{\mathrm{a}} \pm 0.62$ & $40.91^{b} \pm 1.03$ & $39.25^{\mathrm{b}} \pm 1.12$ & $23.79 * *$ \\
\hline Lymphocytes (\%) & $63.62^{\mathrm{b}} \pm 0.41$ & $63.37^{b} \pm 0.26$ & $62.33^{b} \pm 0.43$ & $62.75^{\mathrm{b}} \pm 0.50$ & $55.16^{\mathrm{a}} \pm 0.96$ & $57.0^{\mathrm{a}} \pm 1.06$ & $24.67 * *$ \\
\hline Monocytes (\%) & $2.5 \pm 0.18$ & $2.5 \pm 0.26$ & $2.66 \pm 0.22$ & $2.75 \pm 0.21$ & $2.41 \pm 0.14$ & $2.16 \pm 0.16$ & $1.13^{\mathrm{NS}}$ \\
\hline Eosinophils (\%) & $1.5 \pm 0.26$ & $1.75 \pm 0.25$ & $1.66 \pm 0.25$ & $1.08 \pm 0.31$ & $1.5 \pm 0.19$ & $1.58 \pm 0.14$ & $0.94^{\mathrm{NS}}$ \\
\hline Basophils (\%) & $0.25^{\mathrm{ab}} \pm 0.16$ & $0.37^{\mathrm{ab}} \pm 0.18$ & $0.5^{\mathrm{b}} \pm 0.15$ & $0.25^{\mathrm{ab}} \pm 0.13$ & $0^{\mathrm{a}} \pm 0$ & $0^{\mathrm{a}} \pm 0$ & $3.11 *$ \\
\hline
\end{tabular}

NS - Not Significant * Significant $(\mathrm{P} \leq 0.05) * *$ Highly Significant $(\mathrm{P} \leq 0.01)$; Means bearing the same superscript within the same row do not differ significantly.

et al., 2012). With respect to Basophils a significant $(\mathrm{P} \leq$ 0.05) difference was observed between the sub-clinical pregnancy toxaemic group to that of control.

The Mean \pm S.E. of Blood Urea Nitrogen, Creatinine, Aspartate aminotransferase, Alanine aminotransferase, Glucose and Total Protein in control and pre and post treatment of sub-clinical pregnancy toxaemic group are presented in Table 3. A highly significant $(\mathrm{P} \leq 0.01)$ difference was observed between sub-clinical pregnancy toxaemic group and control in blood urea nitrogen and creatinine levels. Elevated levels observed in sub-clinical pregnancy toxaemic does concurred with Hefnawy et al. (2011). The value of blood urea nitrogen started to decrease by $2.64 \%$ and creatinine by $8.27 \%$ during the course of treatment in sub-clinical pregnancy toxaemic does. The reason for increased blood urea nitrogen and creatinine levels observed in the sub-clinical pregnancy toxaemic does may be due to severe kidney dysfunction due to the elevated ketone bodies in general circulation (El-Sayed and Siam, 1994), or due to reduced glomerular filtration due to fatty infiltration in tubular epithelium of kidney (Barakat et al., 2007) or due to death and decomposition of fetuses (Radostits et al., 2000).

A highly significant $(\mathrm{P} \leq 0.01)$ difference in aspartate aminotransferase and alanine aminotransferase levels was observed between the pre and post treatment of subclinical pregnancy taxaemia groups compared with that of control. Elevated activity of the enzymes correlated with Barakat et al. (2007). However the levels of the enzymes started to decrease during the course of treatment in the post treatment group. The reasons for increased aspartate aminotransferase and alanine aminotransferase activities 
Table 3: Mean \pm S.E. of Serum Biochemical Parameters in Control and Pre and Post Treatment of Sub Clinical Pregnancy Toxaemic Group

\begin{tabular}{|c|c|c|c|c|c|c|c|}
\hline \multirow{3}{*}{ Parameters } & \multicolumn{4}{|c|}{ Control : Pregnant Does - Gestation in days } & \multicolumn{2}{|c|}{$\begin{array}{c}\text { Sub Clinical Pregnancy } \\
\text { Toxaemic Group }\end{array}$} & \multirow{3}{*}{ 'F' value } \\
\hline & \multicolumn{2}{|c|}{$\begin{array}{l}\text { Livestock Farm Complex } \\
(\mathrm{n}=12)\end{array}$} & \multicolumn{2}{|c|}{$\begin{array}{l}\text { ECR Goat Farm } \\
(\mathrm{n}=12)\end{array}$} & \multirow{2}{*}{$\begin{array}{l}\text { Pre Treatment } \\
-(n=12)\end{array}$} & \multirow{2}{*}{$\begin{array}{l}\text { Post Treatment } \\
(n=12)\end{array}$} & \\
\hline & 120 days & 150 days & 120 days & 150 days & & & \\
\hline Blood Urea Nitrogen (mg/dL) & $26.02^{\mathrm{a}} \pm 1.10$ & $26.73^{\mathrm{a}} \pm 1.14$ & $24.77^{\mathrm{a}} \pm 1.13$ & $24.90^{\mathrm{a}} \pm 0.82$ & $39.70^{b} \pm 0.56$ & $38.65^{b} \pm 0.52$ & $69.13^{* *}$ \\
\hline Creatinine (mg/dL) & $0.62^{\mathrm{a}} \pm 0.04$ & $0.76^{\mathrm{a}} \pm 0.04$ & $0.76^{\mathrm{a}} \pm 0.04$ & $0.73^{\mathrm{a}} \pm 0.02$ & $1.45^{\mathrm{b}} \pm 0.09$ & $1.33^{\mathrm{b}} \pm 0.09$ & $26.40 * *$ \\
\hline $\begin{array}{l}\text { Aspartate aminotransferase } \\
(\mathrm{AST})(\mathrm{IU} / \mathrm{L})\end{array}$ & $121.5^{\mathrm{c}} \pm 3.92$ & $122.25^{\mathrm{c}} \pm 1.79$ & $105.5^{\mathrm{a}} \pm 3.04$ & $112.91^{\mathrm{b}} \pm 0.99$ & $131.51^{\mathrm{d}} \pm 1.12$ & $128.1^{\mathrm{cd}} \pm 1.08$ & $26.38^{* *}$ \\
\hline $\begin{array}{l}\text { Alanine aminotransferase } \\
(\mathrm{ALT})(\mathrm{IU} / \mathrm{L})\end{array}$ & $24.12^{\mathrm{a}} \pm 1.24$ & $26.12^{\mathrm{a}} \pm 0.66$ & $44.41^{\mathrm{b}} \pm 2.14$ & $45.41^{\mathrm{b}} \pm 1.99$ & $49.23^{b} \pm 2.02$ & $47.51^{b} \pm 1.78$ & $30.14 * *$ \\
\hline Glucose $(\mathrm{mg} / \mathrm{dL})$ & $25.25^{\mathrm{a}} \pm 2.15$ & $29.25^{\mathrm{b}} \pm 1.66$ & $31.08^{\mathrm{bc}} \pm 1.72$ & $30.08^{\mathrm{b}} \pm 1.15$ & $32.0^{\mathrm{bc}} \pm 0.69$ & $35.0^{\mathrm{c}} \pm 0.51$ & $5.38 * *$ \\
\hline Total Protein $(\mathrm{g} / \mathrm{dL})$ & $6.57^{\mathrm{ab}} \pm 0.25$ & $6.77^{\mathrm{bc}} \pm 0.07$ & $7.11^{\mathrm{c}} \pm 0.13$ & $7.12^{\mathrm{c}} \pm 0.12$ & $6.36^{\mathrm{a}} \pm 0.07$ & $6.46^{\mathrm{ab}} \pm 0.06$ & $7.44 * *$ \\
\hline
\end{tabular}

** Highly Significant $(\mathrm{P} \leq 0.01)$; Means bearing the same superscript within the same row do not differ significantly.

in the sub-clinical pregnancy toxaemic group might be due to the damage of the hepatic cells and release of cellular enzymes into circulation as a result of fatty infiltration of the liver due of adipolysis and hepatic ketogenesis following energy deficit (Nassif et al., 2005).

A highly significant $(\mathrm{P} \leq 0.01)$ difference in glucose level was observed between the post treatment sub-clinical pregnancy toxaemic group and control group. The value of glucose started to increase during the course of treatment in the post treatment group. The hypoglycemia observed in sub-clinical pregnancy toxaemic group might be due to long periods of starvation (Andrews, 1997) or due to the increased demand for glucose by the developing twins or triplets or due to decreased hepatic gluconeogenesis and hypoglycemic effect by the increased level of BHBA in blood which can suppress endogenous glucose production and reduction in food intake (Marteniuk and Herdt, 1988; Schlumbohm and Harmeyer, 2004).

A highly significant $(\mathrm{P} \leq 0.01)$ difference was observed in protein levels between the pregnant does of ECR Goat Farm, pregnant does of LFC at 120 days of pregnancy and sub- clinical pregnancy toxaemic group. Decreased protein levels were observed in sub-clinical pregnancy toxaemic group compared to that of control concurred with Barakat et al. (2007) and Hefnawy et al. (2011). The total protein levels started to increase during the course of treatment in the post treatment group. The reason for decreased total protein levels observed in the sub-clinical pregnancy toxaemic group might be due to the anorexia and reduction in albumin synthesis due to hepatic insufficiency and albuminuria (Yarim and Ciftci, 2009) or it might be due to malnutrition resulting in inadequate provision of amino acid substrate for general protein production (Nasr et al., 1997).

The Mean \pm S.E. of Sodium, Potassium, Calcium, Magnesium and Chloride in control and sub-clinical pregnancy toxaemic group are presented in Table 4.

A highly significant $(\mathrm{P} \leq 0.01)$ difference in sodium levels was observed between pre and post treatment groups of sub-clinical pregnancy toxaemic group, pregnant does of ECR Goat Farm and pregnant does of LFC at 150 days of pregnancy. However hyponatremia was observed in sub-clinical pregnancy toxaemic group correlated with Hefnawy et al. (2011). The value of sodium started to increase during the course of treatment in the subclinical pregnancy toxaemic group. The hyponatremia observed might be attributed to the decrease in feed intake, dehydration or large quantity of sodium loss in the renal excretion of acetoacetate and beta hydroxybutyrate (Judith and Thomas, 1988).

A highly significant $(\mathrm{P} \leq 0.01)$ difference in potassium levels was observed between pre and post treatment of sub-clinical pregnancy toxaemic group compared with that of pregnant does of LFC. Hypokalemia observed in subclinical pregnancy toxaemic group compared to control 
Table 4: Mean \pm S.E. of Serum Electrolytes in Control and Pre and Post Treatment of Sub Clinical Pregnancy Toxaemic Group

\begin{tabular}{|c|c|c|c|c|c|c|c|}
\hline \multirow{3}{*}{ Parameters } & \multicolumn{4}{|c|}{ Control : Pregnant Does - Gestation in days } & \multicolumn{2}{|c|}{$\begin{array}{c}\text { Sub Clinical Pregnancy } \\
\text { Toxaemic Group }\end{array}$} & \multirow{3}{*}{ ' 'F' value } \\
\hline & \multicolumn{2}{|c|}{$\begin{array}{l}\text { Livestock Farm Complex } \\
(\mathrm{n}=12)\end{array}$} & \multicolumn{2}{|l|}{$\begin{array}{l}\text { ECR Goat Farm } \\
(\mathrm{n}=12)\end{array}$} & \multirow{2}{*}{$\begin{array}{l}\text { Pre Treatment } \\
-(n=12)\end{array}$} & \multirow{2}{*}{$\begin{array}{l}\text { Post Treatment } \\
(\mathrm{n}=12)\end{array}$} & \\
\hline & 120 days & 150 days & 120 days & 150 days & & & \\
\hline Sodium $(\mathrm{mmol} / \mathrm{L})$ & $142.2^{\mathrm{ab}} \pm 0.45$ & $154.45^{\mathrm{d}} \pm 1.04$ & $146.35^{\mathrm{c}} \pm 0.75$ & $145.97^{\mathrm{c}} \pm 0.48$ & $141.33^{\mathrm{a}} \pm 0.35$ & $143.18^{\mathrm{b}} \pm 0.29$ & $56.22 * *$ \\
\hline Potassium $(\mathrm{mmol} / \mathrm{L})$ & $5.37^{\mathrm{b}} \pm 0.15$ & $5.43^{\mathrm{b}} \pm 0.10$ & $4.94^{\mathrm{a}} \pm 0.09$ & $5.08^{\mathrm{a}} \pm 0.08$ & $4.89^{\mathrm{a}} \pm 0.04$ & $5.05^{\mathrm{a}} \pm 0.03$ & $6.09^{* *}$ \\
\hline Chloride $(\mathrm{mmol} / \mathrm{L})$ & $108.38^{\mathrm{a}} \pm 0.56$ & $109.61^{\mathrm{b}} \pm 0.76$ & $108.75^{\mathrm{ab}} \pm 0.38$ & $108.72^{\mathrm{ab}} \pm 0.30$ & $111.50^{\mathrm{c}} \pm 0.17$ & $111.09^{c} \pm 0.22$ & $12.39 * *$ \\
\hline Calcium (mg/dL) & $12.71^{\mathrm{c}} \pm 0.61$ & $12.17^{\mathrm{c}} \pm 0.17$ & $11.35^{\mathrm{b}} \pm 0.10$ & $11.32^{\mathrm{b}} \pm 0.15$ & $9.75^{\mathrm{a}} \pm 0.11$ & $9.95^{\mathrm{a}} \pm 0.09$ & $26.21 * *$ \\
\hline Magnesium (mg/dL) & $3.03^{c} \pm 0.05$ & $3.03^{\mathrm{c}} \pm 0.04$ & $3.05^{\mathrm{c}} \pm 0.05$ & $3.09^{\mathrm{c}} \pm 0.06$ & $2.57^{\mathrm{a}} \pm 0.04$ & $2.8^{\mathrm{b}} \pm 0.06$ & $14.55^{* *}$ \\
\hline
\end{tabular}

** Highly Significant $(\mathrm{P} \leq 0.01)$; Means bearing the same superscript within the same row do not differ significantly.

correlated with Albay et al. (2014). The value of potassium started to increase during the course of treatment in subclinical pregnancy toxaemic group. The hypokalemia observed in pregnancy toxaemic does may be attributed to the decrease in feed intake and dehydration (Judith and Thomas, 1988) or may be due to inadequate feed intake and incomplete renotubular absorption of potassium (Henze et al., 1998), or may be due to lowered feed intake and due to los of potassium ions in the urine as observed in human patients with ketonuria and ketoacidosis (Lima et al., 2016).

A highly significant $(\mathrm{P} \leq 0.01)$ difference was observed in calcium levels between pre and post treatment groups of sub-clinical pregnancy toxaemic group and control. The hypocalcemia observed in sub-clinical pregnancy toxaemic group correlated with Hefnawy et al. (2011). The level of calcium in sub-clinical pregnancy toxaemic group started to increase during the course of treatment. The hypocalcemia observed in sub-clinical pregnancy toxaemic goats may be due to the disturbance in the electrolytes and minerals which might be due to stress of starvation, dehydration, electrolyte imbalance or due to enhanced lipolysis (Judith and Thomas, 1988). Alternate reasons might be due to the high demand of calcium by the developing offspring at the late stage of gestation, due to enhanced lipolysis as a result of high cortisol level in circulation, or fatty liver interfering with hydroxylation of Vitamin D and decreased intestinal absorption of calcium (Andrews, 1997) or anorexia and disturbance of acid base balance (acidosis) with the excretion of calcium ions in urine or might be the sequelae to renal insufficiency (Rook, 2000).
A highly significant $(\mathrm{P} \leq 0.01)$ difference was observed in magnesium levels between pre and post treatment of subclinical pregnancy toxaemic group compared with that of control. The hypomagnesemia observed in sub-clinical pregnancy toxaemic group correlated with Hefnawy et al. (2011). However the magnesium levels started to increase during the course of treatment. Hypomagnesemia in pregnancy toxaemic goats may be due to the disturbance in the electrolytes and some minerals related to stress of starvation, dehydration, involvement of the kidney or due to enhanced lipolysis (Judith and Thomas, 1988).

A highly significant $(\mathrm{P} \leq 0.01)$ difference in chloride levels was observed between sub- clinical pregnancy toxaemic group and control. The hyperchloridemia observed in sub-clinical pregnancy toxaemic group correlated with Abdallah et al. (2015). However the value of chloride started to decline in the post treatment group. The reasons for hyperchloridemia in sub-clinical pregnancy toxaemia might be attributed to the metabolic acidosis as a result of proportionally smaller loss of chloride than bicarbonate and improved renal reabsorption of chloride in response to decreased bicarbonate (Kaneko et al., 1997).

The Mean \pm S.E. of serum beta hydroxybutyric acid $(\mu \mathrm{mol} / \mathrm{L})$, non esterified fatty acid $(\mu \mathrm{mol} / \mathrm{L})$ and cortisol (nmol/L) concentration in control and sub-clinical pregnancy toxaemic group assessed by ELISA method are presented in Table 5.

A highly significant $(\mathrm{P} \leq 0.01)$ difference in serum beta hydroxybutyric acid concentration was observed between sub clinical pregnancy toxaemic group and control which correlated with the findings of Ismail et al. (2008). Elevated levels of beta hydroxybutyric acid in the blood 
Table 5: Mean \pm S.E. of Serum Beta Hydroxybutyric acid (BHBA), Non Esterified Fatty Acid (NEFA) and Cortisol Concentration by ELISA method in Control and Sub Clinical Pregnancy Toxaemic Group

\begin{tabular}{lllll}
\hline & \multicolumn{2}{c}{ Control : Livestock Farm Complex (LFC) } & Sub Clinical Pregnancy \\
\cline { 2 - 5 } Parameters & $\begin{array}{l}\text { Pregnant Does } \\
\mathbf{1 2 0} \text { days } \\
(\mathbf{n}=\mathbf{1 2})\end{array}$ & $\begin{array}{l}\text { Pregnant Does } \\
\mathbf{1 5 0} \text { days } \\
(\mathbf{n}=\mathbf{1 2})\end{array}$ & $\begin{array}{l}\text { Toxaemic Group } \\
(\mathbf{n}=\mathbf{1 2})\end{array}$ & 'F' value \\
\hline $\begin{array}{l}\text { Beta hydroxybutyric acid (BHBA) } \\
(\mu \mathrm{mol} / \mathrm{L})\end{array}$ & $275.0^{\mathrm{c}} \pm 31.34$ & $312.5^{\mathrm{c}} \pm 29.51$ & $1308.33^{\mathrm{a}} \pm 58.34$ & $8.86^{* *}$ \\
$\begin{array}{l}\text { Non Esterified Fatty Acid (NEFA) } \\
(\mu \mathrm{mol} / \mathrm{L})\end{array}$ & $406.56 \pm 49.23$ & $434.42 \pm 77.14$ & $534.52 \pm 89.17$ & $2.03^{\mathrm{NS}}$ \\
Cortisol $(\mathrm{nmol} / \mathrm{L})$ & $295.61^{\mathrm{a}} \pm 54.53$ & $348.32^{\mathrm{a}} \pm 33.98$ & $600.76^{\mathrm{b}} \pm 111.55$ & $6.13^{* *}$ \\
\hline
\end{tabular}

NS - Not Significant; ** Highly Significant $(\mathrm{P} \leq 0.01)$; Means bearing the same superscript within the same row do not differ significantly.

might be attributed to the oxidation of long chain fatty acids into ketone bodies namely acetoacetate and beta hydroxy butyrate in the liver following lipolysis during periods of negative energy balance (Nassif et al., 2005) or to the reduction of acetoacetate produced by the liver to beta hydroxybutyrate by hydroxybutyrate dehydrogenase enzyme amounting to higher blood concentration of beta hydroxybutyrate (Hefnawy et al., 2011). Elevated level of serum non esterified fatty acid in sub-clinical pregnancy toxaemic does correlated with Ismail et al. (2008). Elevated levels of non esterified fatty acid might be the result of adipolysis during periods of negative energy balance (Vasava et al., 2016). A highly significant $(\mathrm{P} \leq 0.01)$ difference in serum cortisol concentration was observed between sub-clinical pregnancy toxaemic group and control. Increasing trend of cortisol concentration in pregnant and sub-clinical pregnancy toxaemic does correlated with Abdallah et al. (2015). Increase in cortisol concentration might be due to hyperactivity of the adrenal glands as a result of hypoglycemia (Adel et al., 2005) or due to reduced hepatic metabolism of cortisol (Radostits et al., 2000) or due to increasing stress in the pregnant animals (Aly and Elshahawy, 2016).

\section{CONCLUSION}

The present study showed a cure rate of $100 \%$ in subclinical pregnancy toxaemic does. The early indicators of sub-clinical form of pregnancy toxaemia include presence of ketone body in the urine and blood BHBA concentration $\geq 0.8 \mathrm{mmol} / \mathrm{L}$. Hence, the determination of blood BHBA concentration using a portable blood ketone meter and qualitative urinalysis using urine dip stick for the presence of ketone bodies are reliable indicators in the diagnosis of sub-clinical form of pregnancy toxaemia under field conditions.

\section{ACKNOWLEDGEMENTS}

The authors duly thank the Dean, Madras Veterinary College and Director of Clinics, Tamil Nadu Veterinary and Animal Sciences University for providing necessary facilities to carry out the research work.

\section{REFERENCES}

Abdallah, A.A.M., El-Deen, N.A.M.N. and Ibrahim, A.A. 2015. Early biomarkers for diagnosis and prognosis of pregnancy toxemia in goats. Zag. Vet. J., 43: 130-142.

Abdelghafar, R.M., Ahmed, B.M., Ibrahim, M.T. and Mantis, P. 2011. Prediction of gestational age by transabdominal real time ultrasonographic measurements in Saanen goats (Capra hircus). Global Veterinaria., 6: 346-351.

Adel, M.A., Sahar, S. and El-Hamied, A. 2005. Anion gap determination and its relationship to some serum biochemical indicators in pregnancy toxemia in does. Zag. Vet. J., 33: 162168.

Albay, M.K., Karakurum, M.C., Sahinduran, S., Sezer, K. and Yildiz, R. 2014. Selected serum biochemical parameters and acute phase protein levels in a herd of Saanen goats showing signs of pregnancy toxaemia. Vet. Med., 59: 336-342.

Alidadi, N., Rafia, S. and Moaddab, H. 2012. Outbreak of primary pregnancy toxemia in fat tailed ewes due to ultrasonographic misdiagnosis of pregnancy. Ir. J. Vet. Res., 13: 870-879.

Aly, M.A. and Elshahawy, I.I. 2016. Clinico-biochemical diagnosis of pregnancy toxaemia in ewes with special reference to novel biomarkers. Alex. J. Vet. Sci., 48: 96-102. 
Andrews, A. 1997. Pregnancy toxaemia in the ewe. In Pract., 19: 306-312.

Barakat, S.E.M., Al-Bhanasawi, N.M., Elazhari, G. and Bakhiet, A.O. 2007. Clinical and serobiochemical studies on naturally occuring pregnancy toxaemia in Shammia goats. J. Anim. Vet. Adv, 6: $768-772$.

Cleon, V.K. 1988. Disease of Sheep. $3^{\text {rd }}$ Edn., Lea and Febiger, Philadelphia, U.S.A.

El-Sayed, R. and Siam, A. 1994. Pregnancy toxaemia in ewes. Alex. J. Vet Sci., 1 : 31- 35.

Emam, E.E. and Galhoom, K.I. 2008. Hormonal, haematological blood biochemical changes in pregnancy toxaemia in Balady goats (Caprines caprina) with trials of treatment as a field study. Egypt J. Comp. Pathol. Clinic. Pathol., 21: 121- 138.

Franklin, S.T. and Young, J.W. 1991. Effects of ketones, acetate, butyrate and glucose on bovine lymphocyte proliferation. $J$. Dairy Sci., 74: 2507-2514.

Hefnawy, A.E., Shousha, S. and Youssef, S. 2011. Hematobiochemical profile of pregnant and experimentally pregnancy toxemic goats. J. Basic Appl. Chem., 1: 65-69.

Henze, P., Bickhardt, K., Fuhrmann, H. and Sallmann, H.P. 1998 Spontaneous pregnancy toxaemia (ketosis) in sheep and the role of insulin. J. Am. Vet. Med. Assoc., 45: 255-266.

Ismail, Z.A.B., Al-Majali, A.M., Amireh, F. and Al- Rawashdeh, O.F. 2008. Metabolic profiles in goat does in late pregnancy with and without subclinical pregnancy toxemia. Vet. Clin. Pathol., 37: 434-437.

Judith, V.M. and Thomas, H.H. 1988. Pregnancy toxemia and ketosis in ewes and does. Vet. Clin. Nr. Am. Food Anim. Pract., 4: 307-315.

Kaneko, J.J., Harvey, J.W. and Bruss, M.L. 1997. Clinical Biochemistry of Domestic Animals. $5^{\text {th }}$ Edn., Academic Press, California, U.S.A.

Lima, M.S., Pascal, R.A. and Stilwell, G.T. 2012. Glycemia as a sign of the viability of the fetuses in the last days of gestation in dairy goats with pregnancy toxemia. Ir. Vet. J., 65: 136-148.

Lima, M.S., Silveira, J.M., Carolino, N., Lamas, L.P., Pascoal, R.A. and Hjerpe, C.A. 2016.

Usefulness of clinical observations and blood chemistry values for predicting clinical outcomes in dairy goats with pregnancy toxaemia. Ir. Vet. J., 69: $16-24$.
Marteniuk, J.V. and Herdt, T.H. 1988. Pregnancy toxemia and ketosis of ewes and does. Vet. Clin. Nr. Am. Food Anim. Pract., 4: 307-315.

Nasr, M., Fauad, F.M. and El-Said, B. 1997. Studies on pregnancy toxaemia in does. Alex. J. Vet. Sci., 13: 79-86.

Nassif, M.N., Hafez, A.M., Nasser, M.H. and Tahoon, A.M. 2005. Clinico-biochemical studies on experimentally induced pregnancy toxemia in does. Zag. Vet. J., 33: 31-41.

Pichler, M., Damberger, A., Amholdt, T., Schwendenwein, I. and Gasteiner, J. 2014. Evaluation of 2 electronic handheld devices for diagnosis of ketonemia and glycemia in dairy goats. J. Dairy Sci., 97: 7538 - 7546.

Radostits, O, M., Blood, D.C. and Gay, C.C. 2000. Veterinary Medicine. A Textbook of the Diseases of Cattle, Sheep, Pigs, Goats and Horses. ${ }^{\text {th }}$ Edn., W.B. Saunders, Canada.

Schlumbohm, C. and Harmeyer, J. 2004. Hyperketonemia impairs glucose metabolism in pregnant ewes. J. Dairy Sci., 87: $350-358$

Schlumbohm, C. and Harmeyer, J. 2008. Twin pregnancy increases susceptibility of ewes to hypoglycemic stress and pregnancy toxemia. Res. Vet. Sci., 84: 286-299.

Sharma, N., Kumar, A., Kumar, R., Pawaiya, R.V.S. and Chaturvedi, V. 2014. Metabolic profiling for diagnosis and control of metabolic diseases in goats 2013-14. CIRG Annu. Rep., 4: 64-65.

Van Saun, R.J. 2000. Pregnancy toxemia in a flock of sheep. $J$. Am. Vet. Med. Assoc., 217: 1536 - 1539.

Vasava, P.R., Jani, R.G., Goswami, H.V., Rathwa, S.D. and Tandel, F.B. 2016. Studies on clinical signs and biochemical alteration in pregnancy toxemic goats. Vet. World., 9: 869874.

Yadav, S.N., Kalita, D.N., Phukan, A., Tamuly, S., Dutta, T.C. and Mahato, G. 2016. Diagnosis of caprine ketosis using human hand held ketone meter. Bangl. J. Vet. Med., 14: 179 -181 .

Yarim, G.F. and Ciftci, G. 2009. Serum protein pattern in ewe with pregnancy toxaemia. Vet. Res. Commun., 33: 431-438. 
